DOI https://doi.org/10.36059/978-966-397-225-1-5

\title{
CULTURAL FACTORS AND ELEMENTS OF THE POSTMODERN ARCHITECTURAL DESIGN FORMING
}

\section{Bondar Ihor}

\section{INTRODUCTION}

In today`s context, one of the leading, relevant and sophisticated trends of creative thinking is architecture. It is a massive experiment of both predictive and project-based artistic immersion in the space of the future. There is also a theoretical and practical symbiosis of cultural practices, which turns into a show, into a particular system of dialogue of all other semiological and linguistic models of architectural language, which becomes a self-sufficient mechanism of culture forming. Architectural reflection becomes a symbiosis of philosophical, cultural, linguistic, artistic and architectural thoughts, where the architecture expert appears as a philosopher of space and time.

In modern "non-linear" architecture, buildings are transformed into design objects, and design technologies are ahead of other artistic practices of postmodernism. However, such features of postmodern architecture as uncertainty, fragmentary, unpresentability, irony, carnivalisation, deconstructivism, immanence are pervasive. Only the external phenomenological reality of architectural creativity changes, as the state of absolute destruction, uncertainty, anxiety and restlessness remains identical. It means that the design objects of architecture as a cultural and historical reality produce and demonstrate self-sufficient disharmony, which turns into a new world of postmodernism, which includes irony and self-denial of creativity. In architecture, time is always equal to eternity because sometimes architectural constructions turn into a means of denying eternity and demonstrating the variability of being. The architecture dynamics is close to the dynamics of living objects, as a peculiar aesthetic phenomenon of the evolution of architectural creativity of postmodernism. In postmodern architecture, most of the realities of the technocentric paradigm, where IT technologies come into almost direct contact with nature, make it possible to shape the mission statement of architects.

\section{Aesthetic Features of Postmodernism Architecture Forming}

The artistic dimension of cultural practices of architecture had an adequate definition in philosophy and cultural studies. In particular, the 
change of structuralism by poststructuralism is associated with linguistic, semiological, and phenomenological movements made it possible to create a metalanguage of culture, to which, in the end, the architectural practice of postmodernism turned. It is a reasonably broad program that has found various means of implementation, formed on reconstruction, as well as late mythologemes of folds, rhizomes and plateaus. After all, the Art Nouveau style as a total culture-forming guideline has already introduced a reflexive dimension, which provoked all the following problems of postmodern art. The new aesthetics of the postmodern movement is only being formed and outlines specific configurations. A rather vague reality is defined where a non-linear text or non-linear architecture, the aesthetics of trust in nature and feeling. Therefore, the identification of culture-forming realities at the level of form and image was carried out through a personal approach, one's own mythologeme and methods of handling the tools of culture. Postmodern sensuality from palimpsest, pastiche and collage turns into a rhizome (fr. Rhizome -"rootstock"), as a confrontation with immutable linear structures (being, thinking, etc.), where the plateau of forms creates its random topology, which must be catastrophic, dramatic, stochastic, and unpredictable. However, all the aesthetic features of this movement do not have any established nominations yet, but they already confirm the end of the period of disorder and chaocosm. A new cosmos is formed on the basis of the total sounding of natural dimensions, which indicate the place of a person in the Universe, Earth the planet and create entirely new spatial realities of architecture. The point is that a vast range of transformations of current guidelines, which are understood as ornamentalism, theurgism and vitalism. The design and architectural character of postmodernism follow the modernist principle of vitalism and bionics. And if bionics is only a modelling principle, then vitalism belongs to the philosophy of life. ${ }^{1}$

Thus, the whole context of stylistic dimensions and directions of culture formation has a multitude of allusions and manifestations and is reflected in culture in different ways.

At the same time, allusionism (from the Latin "alludo" - to joke, to hint), as an act of cultural and historical response, which deliberately determines the principle of shaping and turn to certain cultural realities, becomes the starting point in the architectural design of postmodern poetics. But it does not always occur in the form of a direct citation, but, more often, it is a secret reference from an unknown ancestral homeland, determined by one or another cultural reality. The universalism of culture in the form of the Agraf.

${ }^{1}$ Gabrichevskii A.G. (2002) Morfologiia iskusstva [Morphology of Art]. Moskva: 
ancestral homeland becomes a mystified principle of unification into integrity. After all, allusionism is a mixed reality, although it is not combined with eclecticism, as a more reflexive and culturally defined intuition.

Intuitionism as a principle of allusions, the principle of creative impulse comes both from the architect and the viewer or the consumer. Intuition becomes a universal insight of integrity, which may or may not happen simultaneously " in the here and now". Intuition as an immersion in the subconscious cultural memory or the collective subconscious is more organic and fundamental to defining the principle of shaping in the architecture of postmodernism. ${ }^{2}$ Thus there is a binary opposition of structures, which is associated with double coding. The reality of the game is formed as a psychedelic design, as what happens in the context of language games, dialogue, polylogue and other principles of postmodern aesthetics, which define a more psychogenic or culturogenic dimension of form than its formal or only professional aesthetics.

Intuition as a specific technology is carried out by capturing the audience, identity is "adhok" (adaptation to the given goal), which changes continuously and elevates the viewer to the level of the absolute. Adhocism as a project concept that takes into account the realities of the given place, the specific circumstances and features of the cultural and landscape and anthropogenic situation means a method of architectural design, where certain realities are created "in the here and now". ${ }^{3}$ It is a specific reaction to mannerism and modernistic metaphysics, which did not take into account any of the situations and responses in which a particular architectural object arose. Appropriateness, constancy and immersion in the context at the same time are ones of those elements that develop the principle of allusions to the concept of "adhok". The idea of the so-called "ethicist sensuality", which is a component of "postmodern sensuality", defines those values that become important precisely in the context of the "here and now", in the context of the current perception of architectural realities and providing them cultural and historical values which is the pleasure from unexpected cognition, the satisfaction with the growth of a viewer's ability to evaluate an innovative, hybrid form, a sense of a viewer's spontaneous ingenuity and the development of his ability to recognise, guess a function, a special type of sentimentality in which a viewer notices signs of the past, a hint of the

\footnotetext{
${ }^{2}$ Iung K. (1992) Fenomen dukha $v$ iskusstve i nauke [The phenomenon of spirit in art and science]. Moscow: Renessans.

${ }^{3}$ Deleuze G. (2010) Tysiachi plato. Kapitalizm i shizofreniia [Thousands of plateaus. Capitalism and Schizophrenia]. Ekaterinburg: U-Faktoriia; Moscow: Astrel.
} 
possibility of creation of new associative connections. As well as the identity and individual approach to the work of art, the superiority is caused by the implicit submission of the object, the principle of love mixed with hatred. A viewer may feel a kind of elation about the destructive adhocist rejection of the usual forms of architecture and purism. ${ }^{4}$ All these features are in any case transformed into a method of collage or a technique of layering discrete elements of culture, which are combined in the space of shaping and mean adhocist sensuality. ${ }^{5}$ Adhocism acquires the features of dialogue, polylogue, semiological, language games. Still, they are masks of irony, the doubling behind which intuition is hidden, defined in such constellations and such figurative innovations.

A specific principle of metaphorisation of reality is collage or bricolage. But it is more archaic than a metaphor because it uses the principle of metonymy, that is, the semi-coherence of objective cultural realities, which become the coherence of the discourses of architectural language, which is interpreted as a dialogue or polylogue, brings the contemplator of culture to the communicative reality, where the contemplator or recipient finds his or her vis-a-vis, that beloved other "I", whom the person treats with respect or neglects it. This "I" is that dialogue subject of creativity which the recipient regards as a subject of discourse. Therefore, the plurality of subjects of architectural discourse or semi-coherence of discourses, where the possibility of the relationship of "you" and "I", "I" and other "I", "I" and the one who engages in conversation, is a participant in the dialogue, creates a postmodern or adhocist sensuality as a many-voiced fabric of the architectural language of postmodern architecture.

It is clear that complications and entering different contexts of allusions together have a generative distinction or a productive paradigm. A productive paradigm is considered to be a game. The game provides an opportunity to combine semiological, linguistic, objective, cultural and historical dimensions of architectural form and give them a general context of existence in the "here and now", in the space of double coding or dialogue, pre-distancing, reference to some still unknown distant horizons of culture or shaping, and at the same time treat them ironically, question them and try to check the rules of the game or the formula of game behaviour.

The sense of an architectural form or architectural object is to create rules of behaviour, rules of the game and force a viewer to engage in this or that

4 Dobritsyina I. (2004). Ot postmodernizma $-k$ nelineynoy arhitekture [From postmodernism to non-linear architecture]. Moscow: Progress-Traditsiya.

${ }^{5}$ Noever P. (ed.) (1991) Architecture in Transition: Between Deconstruction and New Modernism. New York: Prestel Pub. 
dialogue in one way or another. That is, design objects of architecture encourage behaviour that occurs as a movement in space and a specific shorthand transcript of a view of the form. Its definition as a collage, bricolage, ironic or other constellation is a specific installation of objective, symbolic or any other features. All this creates polysemanticity, plurality, multiplicity, understatement, uncertainty and, in a certain way, the marginality of the architectural form, as it loses the textuality of classical culture or the textuality of the prophetic pathos of modernism. There appears what will be later called "pastiche". This is a specific postmodern reality, which is related to a parody or certain ostentation, a comparison of fragments of different works of the new text. There appears a hypertext as a specific mixture, potpourri. Pastiche becomes a certain bound of postmodern art.

Thus, allusionism as a game reality of shaping in postmodern architecture is the dimension that makes it possible to interpret creativity in different landscapes of architecture being as in anthropogenic, geocentric, semiological, linguistic and correlate all these features with the metamorphosis of shaping, which can be called an intuitive insight or insight of integrity based on comparison of hints. Finding, unification and definition of citations, contexts, forms as realities of a certain hypertext or metatext arises in time and the "here and now". ${ }^{6}$ And if we get rid of this dimension, then it will not be postmodern. An allusion is a unity in the present, future and past. The past and the future are manifested by spatial and temporal artefacts, which are defined as metonymy and metaphor. This rhetorical mechanics becomes a language of architectural harmony, but it unfolds consistently in different ways in the work of each master.

However, the principle of allusions cannot be reduced only to reflections, hints and game of cultural and historical type. The unusual for architecture aesthetic categories of comic, palimpsest and irony enter into it.

If the sublime, beauty, harmony are pertain to architecture, then comic and tragedy are not. The tragic, if it exists, then it is in the form of a projection of the image of society on an architectural structure, which is connected with one or another cultural and historical reality. And the comic exists in architecture as a sign of architectural creativity rarely too. It may be a projection, but it is quite far from the architecture itself as an art form. However, postmodern design objects of architecture transcend this bound and introduce the category of "comic" in the context of postmodern aesthetics of architecture. Design objects of architecture tend to transform

${ }^{6}$ Bondar I. S. (2012) Obraznyi potentsial arkhitekturnoho dyzainu postmodernizmu [Figurative potential of architectural design of postmodernism]. Ukrainska kultura: mynule, suchasne, shliakhy rozvytku, vol. 18(1), p. 141. 
irony from a mechanism of pre-distancing and evaluation into a mechanism of evaluation from within or from another context, which gives the architectural text the unity of the composed discourses. The comic element becomes a sign of peculiar architecture. Design objects of architecture encourage a person to depreciate values. There is no eternity, no time, not even space. There is only a game and the ability to evaluate, and the evaluation itself depends on a viewer.

In the architecture of postmodernism there appears a palimpsest also

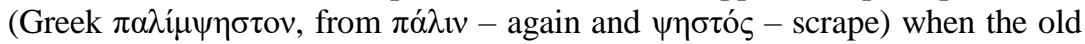
text is erased, and a new one is written on its basis, but the prescriptions, the paradigm of the old text remain. The palimpsest is also a metaphorical image that indicates the reality of postmodern architecture. The palimpsest is an absolute reflection of the past that exists nearby. And not only in the traditional meaning (vertical), in the form of the increase in the imagery of texts since the erased or previous texts are viewed through the fabric of a new one, but also horizontal, when intertextuality is unification in the multi-vector space of architecture - on the left, on the right, above the text. All these definitions become an extremely fruitful means of interpretation and integration of architectural space. At the same time, the redundancy and metaphorical interpretations cannot bring postmodernism to unambiguous statements to which modernism tended and which permeated the classics. The very polyphony of views and possibilities interpretation of the vision is a deep core of the architectural harmony of postmodernism. There comes a time when we cannot interpret reality as a text and say that it is chaos or disorder.

And here irony acts as a crucial mechanism of postmodern poetics. Unlike allusionism, the principle of reflection, dialogue, polylogue, the irony is a more archaic principle, which is related to the dichotomy, the doubling of the discourse subject, to the language of discourse (in this case, the discourse of architecture) is doubled. The subject or semi-subject of the discourse determines the other, and the other is disavowed immediately. Disavowal that is the elimination of other is called "irony". In the postmodern context, ancient irony, the irony of German classical philosophy and the irony of romanticism can be distinguished. ${ }^{7}$ Thus, from ancient, romantic and classical irony, postmodernism turns to cosmological irony. This cosmological irony is the irony of contemplation, the irony of connection with the mysterious absolute of the universe, nature, the macro and micro worlds. That is, there is one step from the active subject-figure to

${ }^{7}$ Losev A. F. (1976) Problemasimvola i realisticheskoeiskusstvo [Symbol Problem and Realistic Art]. Moscow: Iskusstvo; Losev A. F. (1990) Strast k dialektike [Passion for dialectics]. Moscow: Sovetskiipisatel. 
the passive spectator. Postmodernism combines these two figures: the subject-ironist and the subject-spectator because the dynamic-forming dominant was present, namely at the first stage of postmodern architectural development. At the last stage, all shaping returned to contemplation, selfsufficient aesthetics, imitation of nature.

The principle of irony is the doubling of reality and its interpretation. When the architect begins to analyse what is formed, he doubles the world in the "here and now", devalues reality in such a way that defining values he tries, in the manner of ironist, to stand above all the contradictions of the world. Thus, eclecticism becomes the irony of postmodernism, the unity of all possible types - from hidden dialogue, monologue reality to the definition of the absolute through the singular, the test of the absolute for reliability, and, vice versa, the projection of the singular on the Universe.

All these positions can be used in turns or coexist in the same work in the postmodern discourse of architecture. In particular, postmodern philosophy achieves rather complex implications, complex self-definitions, so the double coding was borrowed from literary texts to postmodern architecture. ${ }^{8}$ Irony imitates binarity and continues the same dichotomy code that is typical of archaic systems. It can be claimed that the ironist does not become a dialectician, because dialectics has all the prerequisites for resolving contradictions. The ironist problematises contradictions and eliminates them by expressing the will or by removing one of the objects of ironic disposition - the absolute or the subject.

At the same time, the mechanism of allusion and the mechanism of irony are similar in postmodern aesthetics. The mechanism of allusion begins with a hint and turning to different spatial and different temporal reality. The subject substantiates intuition as an ascending principle of shaping. The mechanism of irony begins with doubling, the dichotomy sinks into the subject and evokes that deep monologuism that tends to dialectics as a unity of contradictions. ${ }^{9}$ This mechanism is objectified and brought out, transformed in the space of all possible worlds. The ironist is like an anonymous figure, and only the irony remains as a game, an echo, a reflection of the worlds.

${ }^{8}$ LiotarZh.F. (1994) Otvetnavopros, chtotakoepostmodern?[The answer to the question, what is postmodernity?]. Ad Marginem '93, pp. 307-323.

${ }^{9}$ Losev A. F. (1976) Problemasimvola i realisticheskoeiskusstvo [Symbol Problem and Realistic Art]. Moscow: Iskusstvo; Losev A. F. (1982) Problema variativnogo funktcionirovaniia zhivopisnoi obraznosti v khudozhestvennoi literature [The problem of the variable functioning of pictorial imagery in fiction]. Literatura $i$ zhivopis [Literature and painting]. Leningrad: Nauka, pp. 31-65. 
It should be noted that irony carries both a mode of negation and a mode of a certain apophatism, that is a description of reality from the standpoint of dissolution, the standpoint of denial. If the phenomenon is not defined, not evident, then it is described in the perspective of those features that may be a negative imprint of this project image. This apophatism, negation is ironic in the sense that it marks the distance, the attitude of a person to an object, and at the same time reduces the pathos of the human "I" to the vagueness of the absolute. Thus, the mechanism of irony in the context of postmodern aesthetics and, in particular, postmodern architecture is complex and multidimensional, and the mechanism of doubling, binarity is saving, but not significant. Eventually, it turns into an infinity of plural worlds that open up in the non-linear space of virtual objects.

Thus, the allusion can be considered as irony and temporality of architecture in the context of the ornamentalism of postmodernism. Everything is an allusion, and all together, they are design objects of architecture. Without culture, without a cultural aura, the design objects of postmodern architecture are impossible. Just as they are impossible without references and intuitionalism, but the differential structural approach tries to determine what is dominant in a particular context of shaping: irony, ornament, etc.

The reflexive field of postmodern theory is constructed as a linguistic configuration based on linguistics and semiology. Eclecticism, discreteness, the harmony of discontinuous structures are the beginning of the postmodern reflexive theory. It is namely with decomposition, dismemberment that the negation of the previous culture begins. Deconstruction is an assembly, where the gathering arises on the basis of dismembered and disordered chaos that falls into the circle of the game, allusions as specific hints and unexpected collisions, fragments of different cultures and different elements of architectural language. That is, adhocism, eclecticism, allusionism are the development of the same principle of cultural and historical hints and intuitionalism as a principle of the unexpected increase in complexity, definition of the image and the emergence of truth that opens suddenly, "here and now", in a particular cultural and historical context of architectural practice.

In an architectural work, adhocism is defined as a kind of polyphonic fabric, where the author remains anonymous among the unlimited polyphony of discourses, which is defined as architectural construction, although in some places it is difficult to consider it as such. Sometimes it is called a 
show space, the use of architectural language ${ }^{10}$, because design objects of architecture begin to speak their language, the language of allusions, the language of hints and the language of intuition, where the integrity is taken out of the contexts of the universe, culture, person and plunges into the subconscious again, forces to sound the subconscious. Any "mind of postmodernism" turns into "madness" and vice versa. Pure madness is impossible here because it is burdened with an extremely complicated game of cultural allusions. And that's why adhocism as appropriateness, as the existence of "here and now" in the context of the Universe, world intuition is a rather disturbing reality, which suggests that postmodernism is not just a restlessness, an escape from the problems of harmony. It is the same harmony, but it is hidden in the realities of objectifying intuition as a generating creative source.

The architecture of postmodernism as cultural and historical reality consolidates and defines an image that can be formed as a whole: the primary simplicity of eclecticism, its globalisation and visualisation; the period of flourishing of postmodernism, related with the formation of concepts, the period of postmodern architecture as a double simplification and the search for natural analogues of design. ${ }^{11}$ Thus, the process of sounding nature becomes a reality of the 20th-21st centuries. The architectdesigner creates a certain meta-screen, a computer analogue of nature, where all the transcripts look like innovative images of the modern space of architecture.

Postmodernism blurs the line between high and elitist art, between architecture as art focused on eternity and everyday life, where design objects of architecture can exist only for a few months, as it will still be architecture with a capital letter. These are so-called pavilion-type assembly facilities that are quickly assembled and disassembled. Every time they please the eye with their new and new forms. Besides, each stage of postmodern architectural creativity used them simultaneously, but one of the models was dominant. At the same time, each stage of postmodern architectural creativity used them simultaneously, but one of the models was dominant. For example, at the early (romantic) stage, eclectic monism and the universality of the absolute were present, at the middle one (period of flourishing complexity) monism and romanticism were present, and, finally, the last stage cannot be deprived of either romanticism or universality, they

${ }^{10}$ Glazyichev V. L. (2002) Arhitektura.Entsiklopediya [Architecture. Encyclopedia]. Moscow: Astrel.

${ }^{11}$ Leontev K. (2003) Khram i tcerkov [Temple and Church]. Moscow: AST. 
exist, but as elements that are determined by monism, turning to the primary sources - natural analogues.

It should be noted that all the possibilities of interpretation of postmodernism enrich the designed experience of a designer and help to see it more voluminous and holistic, without the simplification and schematism that is often present in the characteristics of postmodern aesthetics.

Of great importance in shaping the design of postmodernism is the concept of "installation" (English - instruction, device, construction), as one of the hybrids, mixed genres of visual art. That is, an installation is the arrangement of objects in architecture as a certain configurative reality, the syntagmatic of the architectural space, sort of a cross between a sculpture, a design object and an architectural model. Installation is a variety of structures suspended in the air, assembling in the space of various technical or craft items, various materials: metal, glass, wood, plastic parts, papiermache, etc. Even the very principle of installation indicates museality, museumification, everything that is related to specific conservation of time.

Architecture has always been engaged in creating the world within the established frameworks and dimensions of cultural space, was the epicentre of creation or a model of the universe. Installation or retro-installation means that in architecture, the object of self-sufficient admiration and museumification becomes not architectural forms, but objects alien to the architectural form. There are quite a lot of examples of installation in architecture. It can be a conceptual installation of high-tech architecture, sculptural and technomorphic objects, theatricalisation of architectural space, as well as all postmodern shapes in the form of environment, happening, performance and many other postmodern genres. For example, there are the extravagant inverted pyramids and works of metal pillars by French architect Luc de Le or the "soaring" designs of Zaha Hadid and the "cocktail" sticks by Rem Koolhaas, the "sliding" sloping beams by Frank Gehry and the giant architectural models by Daniel Libeskind. ${ }^{12}$

A retro installation can work with time, where the archaic pre-time unfolds to which the architect appeals, or it can simulate time at the level of vintage style or another retro style, as a temporary visionary game in architecture. Besides, no matter how much the design objects of architecture try to eliminate time in their installations and turn it into a pure space geometric, conceptual, technomorphic - but time, as a certain dimension, is present. That is, the principle of appeal to temporality forms a particular visual phrase anyway (architectural form, symbiosis of forms in architecture,

12 Starodubtseva, L. Arkhitekturapostmodernizmu [The architecture of post modernism]. Kyiv: Spalakh. 
a certain ornamental, patterned space), is a specific dimension of time that exists in the context anyway - "it was". ${ }^{13}$ The design objects of architecture take us back to the past. The modernity looks like what was constructed yesterday, not today.

Thus, installation as an idea of construction is an absolute pervasive principle of architectural creativity of postmodernism, but it is not so clearly defined as deconstruction. And if deconstruction is a mask of European activism and marks the nihilistic phase of form-making, then retroinstallation or installation is a mask of the European type of expansionism. That is, the extensive metric of assimilation of space horizontally, the location of objects is a certain ornamental phase of overcoming space. Here the vertical is a syntagmatically defined object and is determined only as a quantity required to structure the horizontal.

Thus, the installation is the reverse side of deconstruction. It is quite paradoxical because deconstruction cannot occur without the development of its potential, its embodiment in space which is carried out in the form of installation. And here arises the mutagenic object or transmutation as an effect of the action that marks changes in temporality, the transition from one time, one dimension of temporality to another. ${ }^{14}$ It is rather difficult to see this in architecture. Still, it is imperative to find out the language of postmodern architecture as the language of temporality and spatiality of its compositional structures. Thus, the retro installation is a sensual and nostalgic project of postmodernism. Postmodernism is unsurpassed in this. It has the sensuality of the postmodern dimension, which can be called nostalgia for the classics because modernism has lost the classics, and postmodernism wants to return it as a marginal object.

The nostalgia of postmodern sensuality is related to total eclecticism and borrowing of everything: citation, the phenomenological fabric of culture and the horizons of distant worlds, creating a fantastic landscape of culture; installation, as the collapsing and struggling of the world in the context of archetypes acquiring more structural and organ-like dimensions; non-linear architecture. This is nostalgia for the natural universe, for the unity of a person and the universe, a person and nature. Thus, postmodernism is not complete destruction and wave of unbalanced systems. ${ }^{15}$ Aesthetic worldview is present in allusionism and intuitionalism, as well as in nostalgic reality. But

${ }^{13}$ Bart R. (1994) Izbrannyierabotyi: semiotika, poetika [Selected works: semiotics, poetics]. Moscow: Progress.

14 Groys B. (2003) Kommentarii $k$ iskusstvu [Comments on art]. Moscow: Art magazine.

15 Puchkov A. (1997) Arkhitekturagroteska [Grotesque architecture]. A.C.C. Azt. City. Conctruction, № 4, pp. 24-25. 
this is an unusual nostalgia - it does not belong to a separate subject, the soulfulness and mentality of individual "I". The whole complexity of the installation as a nostalgic project is that it tries to be the super-integrity of culture and struggles for eternity for postmodernism, which has not to exist before and which is called - postmodern classicism. ${ }^{16}$ The projection into the space of geometrics, mysticism and horror with its semi-darkness and infinity of dark space takes place. There is no dark space here, only the sky. That is, the phenomenon of nostalgia is felt, where the very appeal to past images is reflected in the topological matrix, a certain spatial installation as a deconstruction of syntagmatics in the space of coexistence of earth and sky. "It's a different approach to interpretation. This image arises from the postmodern standpoint of neo-decorativism when a viewer is invited to value the irony of the inverted image". ${ }^{17}$

It is evident that the installations should be perceived in volume, together, and only then we can see a deep allusion, which is certain nostalgia, an installation - a decorative transformation of the space of ancient cultures in the space of today. This is how the philosophical or architectural principle of shaping takes place, which becomes an installation or super-installation of postmodernism. The vitalistic impulse becomes the generative paradigm of the last post neoclassical stage of shaping in postmodernism. The design objects of architecture are one of the leaders in sounding the integrity of the universe, its vision in the context of all innovations defined as non-linear text, organic architecture, non-Euclidean space, which can be noted at the level of a topology or fractal syntagmatics of form-building intuitions of architectural space. Postmodern vitalism is an interpretive mask of Art Nouveau vitalism but not philosophical vitalism of the philosophy of life.

Thus, the architect-postmodernist, on the one hand, generalises the intuition and tendency of the philosophy of life, because the latter acquires not only romantically defined features, but becomes a certain mechanics borrowed from Leibniz, Descartes and even Kant, and, on the other hand, images of classical harmony are installed in the modern topological dimension of architectural space, transformed in the "fourth dimension".However, this mechanics is only a means of interpretation or an interpretive mechanism for the understanding of formation. So we can say that the theory of fractals, singularities and the possibility of morphogenesis,

\footnotetext{
Respublika.

${ }^{17}$ Glazyichev V. L. (2002) Arhitektura.Entsiklopediya [Architecture. Encyclopedia]. Moscow: Astrel, p. 66.
}

16 Kozlovski P. (1997). Kulturapostmoderna [Postmodern culture]. Moscow: 
that is, shaping as a certain genetic algorithm creates, a peculiar innovative aura of architectural creativity. Warehousing is a kind of seamless unity - it is folding as a flow, as something that allows the shaping of continuous, infinite transformations of reality in the space of innovation.

The harmony of the design and architectural image of postmodernism imitates the modernist principle of vitalism and bionics. But bionics is only a modelling principle, and vitalism of postmodernism is taken from the Art Nouveau style and belongs to the philosophy of life, which is concentrated in the architectural object, understands it as a vitalistic, that is a living organism, which is an analogue of living social systems. ${ }^{18}$ There is no such determinism and dependence on the substantial core, on living systems here. The cover itself becomes a living system that models the concrete core, which flows to the periphery, is marginalised and loses its central position. Thus, the space from the centred, archaic becomes decentralised, and moreover, marginal. Life as a marginal object exists in different dimensions: cultural, ironic, in installations. It can be considered as a bionic structure, that is - instruction of postmodernism focused on the reproduction of plant substructures of the living world in the architecture, which allows hearing this life in the form of proportionality of the substrate of shaping and gravity. Besides, postmodern has no obvious analogues that would reproduce the bionic configuration of plant structures, but it, to one degree or another, tends to model these substructures. Implicitly, bionism arises in the designs of towers, in the images of objects that are created namely as high-tech or neo-constructive ones, but this is not a problem of construction, but modelling of space.

The language of the postmodern architecture of recent decades is certain destruction of J.Deleuze's philosophy. Deconstruction continues to exist as a principle of architectural harmony, and the philosophical model is destructured in architectural theory. This is an intermediate link between vitalism as a principle of living matter and bionics, and as a model of structural organic that exists in architecture. In the "labyrinth of matter", new models appear that allows seeing the universe and resemble certain wavy lines. All this could not but attracted architects. Non-linear design objects of architecture appear right on the bound of the paradigm of harmonious and destructive. "Now under the matter-fold the matter-time can be understood, whose phenomena are similar to the explosions of an infinite number of

\footnotetext{
Agraf.

${ }^{18}$ Gabrichevskii A.G. (2002) Morfologiiaiskusstva [Morphology of Art]. Moscow:
} 
spiritual arquebuses". ${ }^{19}$ But the search for such a universal and figurative constellation, where the matter-fold, the matter-time are understood as a spatial pattern, spatial explosion makes it possible to dissolve this space, and then to talk about its flexibility, labyrinthiness, which allows it to vibrate and create organismic acts. Thus, the context of philosophy includes the concept of the organism, which has become an important principle that emerged in the late 20th century.

Such assimilation of external actions with objects and social forms of communication, where the organism fits into a fold, a spatial labyrinth or a machine as a mechanodeterministic definition of a fold, allows architects to pass from philosophical implications to figurative installations, transformations of that space defined as baroque or principle of folding. ${ }^{20}$ The determination of folding, movement in space is a principle of organismism, which in architecture can be related to organic architecture, Frank Lloyd Wright's Ozonia, and which acquires total and mythogenic characteristics. The division into "first" and "second" floors that marked by culture is as a vertical makes it possible to search for determination from above and below, and the opportunity to imagine unity. A new myth emerges, a new organic unity as a principle of shaping, which is not yet realised by Leibniz's pre-established harmony, but implicitly carries it as allusions, a hint at the European cosmos in the spatial realities of philosophy, culture and architecture.

Singularity as the basis for the continuity of curve creation correlates with points that are the epicentres of curvature (generatrix) and at the same time are the shocks or centres from which radial lines emerge, which create this curvature and are determined by "infection". ${ }^{21}$ At the same time, the principle of inflexion is deeper or more archaic and is a phenomenon of reference to the central space, where the curvature is described from the centre. This approach is interpretive, geometric and helps the architect to describe curves as infinitely fluid on the basis of points, epicentres, which are creative dimensions of the spatial realities of shaping.

The very vision of the modality of curvature as a creative point scattering across the Universe is an interpretive and model principle of postmodern space. Curvature becomes an echo of the architectural curve space, which models the curvature of the universe that indicates a new vitalism and new

19 Deleuze G. (1997) Skladka.Leybnits $i$ barokko [Fold.Leibniz and Baroque]. Moscow: Logos, p. 13.

20 Deleuze G. (1997) Skladka.Leybnits $i$ barokko [Fold.Leibniz and Baroque]. Moscow: Logos.

21 Deleuze G. (1997) Skladka.Leybnits $i$ barokko [Fold.Leibniz and Baroque]. Moscow: Logos. 
bionics. After all, this space is very similar to Cartesian space, where there are no gaps, but there is an infinite fluidity of the masses. And it is in the post-neoclassical definitions of architecture namely that this problem has become extremely relevant. It is about what a creative source is - exterior or interior. Interior space as a centred one, where is a point that allows describing all the forming trends as an "S"-like baroque line or something else is an entirely different dimension, when the architecture itself runs together, shrinks and becomes a repository, an ecological niche of a person. These two problems have not been determined in architecture yet; moreover, no one defines them as shape-generating, but they exist implicitly and dictate the logic of shaping, which occurs today.

The concepts that arise in modern architectural thinking tend to reconstruct the biomorphic or vitalistic paradigms. For architects, it "scatters" in different shape-generating potentials. At the same time, it is namely the design analysis and synthesis in architecture that learns such configurations of thinking as "genetic algorithm", that is it is about stability, inheritance, generation of evolutionary inheritance of processes that should be defined in the context of a particular tech population. ${ }^{22}$ The concept of "tech population" is absolutely identical here, because it refers to high technologies that fall into modern architecture. Moreover, these are high technologies that make it possible to pass from the problem of inquiring and the dichotomous definition of "shape - mass", "mass - space" and others, to the issues of synthesis, since architectural reflection adapts various reflexive contexts, including systemic one. ${ }^{23}$ The design objects of architecture become hyper-intensive strangulation, which tries to gather philosophical, cultural, and scientific data.

Architectonics and plasticity are the extreme dimensions of the temporality and spatiality of an object that exists as a spatial phenomenon of architecture. However, the philosophy of life and the very principle of vitalism in architecture despises this object. The design objects of architecture are only membranes and films, that is, those substructures dividing the space that limit this space. The case of the substantial core or vital organism is constructed as the penetration, breakthrough, spreading of all these films and membranes. ${ }^{24}$ Of course, this is the extremism or expansionism that is typical for European culture and produces the idea of

22 Dobritsyina I. (2004). Otpostmodernizma $-k$ nelineynoyarhitekture [From postmodernism to non-linear architecture]. Moscow: Progress-Traditsiya.

${ }^{23}$ Legenkiy Yu. G. (2005). Ob arhitekture (ocherkiteoriidizaynainterera) [About architecture (essays on the theory of interior design)]. Kyiv: KNUKiM Publishing. Agraf.

${ }^{24}$ Gabrichevskii A.G. (2002) Morfologiiaiskusstva [Morphology of Art]. Moscow: 
European expansionism. Therefore, there is still a certain provocation of the destruction of either the previous culture or all the walls, fences, membranes, which are the norm or established spatial boundary of human activity.

In architecture, folding is understood in both spatial and temporal dimensions. Every energy explosion, every quantum pli (fold) freezes in the topological structure of the work. The topology (spatial meaningfulness) of the work is developed as a synthesising activity, the theory of folding or folds. Thus, topological structures are interpreted as fractals. Fractality allows the architect to model complex organ-like structures mathematically. ${ }^{25}$ The shape, size, number of techniques serve to determine two main functions of the architectural cover, which connects the spatial core with the dynamics of the outside world. ${ }^{26}$

\section{CONCLUSIONS}

Analysing the main culture-forming instructions of the postmodernism architectural design, we can say that the change of structuralism to poststructuralism related to linguistic, semiological, phenomenological movements, made it possible to create a metalanguage of culture, to which the architectural practice of postmodernism turned, having found various means of implementation, because the Art Nouveau style as a total cultureforming guideline has already introduced a reflexive dimension, which provoked all the subsequent problems of postmodern creativity.

It is a massive experiment of both predictive and project-based artistic immersion in the space of the future. A theoretical and practical symbiosis of cultural practices takes place, which turns into a show, into a specific system of dialogue of all other semiological and linguistic models of architectural language, which becomes a self-sufficient mechanism of culture forming.

In the context of postmodernism, we have proved that a symbiosis of stylistic introversions and transgressions, and in architecture and design mainly. It is the so-called stylistic line of deconstruction, which is aimed at installation of the architecture of modernism in the postmodern space. Thus, postmodern as a phenomenon of culture forming in architecture and design undergoes big-picture transformations, which is associated with postmodern aesthetics, which can be called reframing and evolutionary. Transformation as the primary stage of drama of the discrete type forming is transformed

${ }^{25}$ Noever P. (ed.) (1991) Architecture in Transition: Between Deconstruction and New Modernism. New York: Prestel Pub.

${ }^{26}$ Gabrichevskii A.G. (2002) Morfologiia iskusstva [Morphology of Art]. Moscow: Agraf, p. 461. 
into an evolutionary and populist technology of "folding" of space in the shape-generating dimension.

Thus, allusionism, vitalism, pastiche and other realities of the correlation of shape-generating and figurative and symbolic elements of culture in architecture and design are generalised by the mythologeme of the fold, which is a continuous form of collision and flow of space as a combination of forms and implicit destruction of time and space of an architectural structure. Postmodern bionics and vitalism in architecture become that profound artefact and dimension of shaping that reflects the imitation of natural and dimensional features of the anthroposphere, which are modelled in architecture and design as a non-linear space. It proves that the principles of space transformation in non-linear architecture become ambiguous in transformative aesthetics and poetics, a fundamental source of change in the architectural design.

\section{SUMMARY}

The modern world of postmodern culture as disillusionment with the ideals of modernism, characterised by detachment, irony and parody of the present and the past, the time of the "end of everything", shifts to the total state of the whole culture, which produces both works of art and a form of thought. However, in postmodern architecture, there has been a solution that has combined the rationality of modernism with unique art and design works. The relevance of architecture understanding is determined by the fact that historically it is associated with art that concentrates art movements and maintains the style of the era, carries out a symbiosis of artistic practices of immersion in the future, and its language works a self-sufficient mechanism of culture forming. The purpose of the article is to study the features of formative focuses and strategies of postmodern design architecture as a cultural and historical reality. The scientific novelty designates the subject of the techniques of postmodern creativity: allusions, irony, ornamentalism following the cultural and historical existence of postmodern architecture and design. The article describes the form making of postmodernism, the role of architectural creativity in the cultural genesis of postmodernism, and defines the figurative and potential of postmodern architecture. Conclusions. We have proved that the change of structuralism by poststructuralism made it possible to create meta languages of culture, which the architecture of postmodernism turned to by various means of implementation. In the context of postmodernism, there is a symbiosis of stylistic introversions and transgressions, and in architecture and design mainly. Thus, postmodern as a phenomenon of culture forming in architecture and design undergoes bigpicture transformations, which is associated with postmodern aesthetics, 
which can be called reframing and evolutionary. We have learned that postmodern bionics and vitalism in architecture become a dimension of shaping that reflects the features of the anthroposphere modelled in architecture and design as a non-linear space. It proves that the principles of space transformation in non-linear architecture become ambiguous in transformative aesthetics and poetics, a fundamental source of change in the architectural design.

\section{REFERENCES}

1. Bart R. (1994) Izbrannyie rabotyi : semiotika, poetika [Selected works: semiotics, poetics]. Moscow: Progress. (in Russian)

2. Bondar I. S. (2012) Obraznyi potentsial arkhitekturnoho dyzainu postmodernizmu [Figurative potential of architectural design of postmodernism]. Ukrainska kultura: mynule, suchasne, shliakhy rozvytku, vol. 18(1), pp. 138- 142.

3. Deleuze G. (1997) Skladka. Leybnits i barokko [Fold. Leibniz and Baroque]. Moscow: Logos. (in Russian)

4. Deleuze G. (2010) Tysiachi plato. Kapitalizm $i$ shizofreniia [Thousands of plateaus. Capitalism and Schizophrenia]. Ekaterinburg: U-Faktoriia; Moscow: Astrel. (in Russian)

5. Dobritsyina I. (2004). Ot postmodernizma $-k$ nelineynoy arhitekture [From postmodernism to non-linear architecture]. Moscow: ProgressTraditsiya. (in Russian)

6. Gabrichevskii A.G. (2002) Morfologiia iskusstva [Morphology of Art]. Moscow: Agraf. (in Russian)

7. Glazyichev V. L. (2002) Arhitektura. Entsiklopediya [Architecture. Encyclopedia]. Moscow: Astrel. (in Russian)

8. Groys B. (2003) Kommentarii $k$ iskusstvu [Comments on art]. Moscow: Art magazine. (in Russian)

9. Iung K. (1992) Fenomen dukha $v$ iskusstve i nauke [The phenomenon of spirit in art and science]. Moscow: Renessans. (in Russian)

10. Kozlovski P. (1997). Kultura postmoderna [Postmodern culture]. Moscow: Respublika. (in Russian)

11. Legenkiy Yu. G. (2005). Ob arhitekture (ocherki teorii dizayna interera) [About architecture (essays on the theory of interior design)]. Kyiv: KNUKiM Publishing. (in Russian)

12. Leontev K. (2003) Khram i tcerkov [Temple and Church]. Moscow: AST. (in Russian)

13. Liotar Zh.F. (1994) Otvet na vopros, chto takoe postmodern? [The answer to the question, what is postmodernity?]. Ad Marginem'93, pp. 307-323. 
14. Losev A. F. (1982) Problema variativnogo funktcionirovaniia zhivopisnoi obraznosti $\mathrm{v}$ khudozhestvennoi literature [The problem of the variable functioning of pictorial imagery in fiction]. Literatura $i$ zhivopis [Literature and painting]. Leningrad: Nauka, pp. 31- 65.

15. Losev A. F. (1990) Strast $k$ dialektike [Passion for dialectics]. Moscow: Sovetskii pisatel. (in Russian)

16. Losev A. F. (1976) Problema simvola i realisticheskoe iskusstvo [Symbol Problem and Realistic Art]. Moscow: Iskusstvo (in Russian)

17. Noever P. (ed.) (1991) Architecture in Transition: Between Deconstruction and New Modernism. New York: Prestel Pub. (in English)

18. Puchkov A. (1997) Arkhitektura groteska [Grotesque architecture]. A.C.C. Azt. City. Conctruction, № 4, pp. 24-25.

19. Starodubtseva, L. Arkhitektura postmodernizmu [The architecture of postmodernism]. Kyiv: Spalakh. (in Ukrainian)

\section{Information about the author:}

Bondar Ihor orcid.org/0000-0001-8972-0941

Associate Professor

Honoured Worker of Culture of Ukraine Kyiv National University of Culture and Arts 36, Ye. Konovaltsia St., Kyiv, 01133, Ukraine 